\title{
Formação do pensamento brasileiro moderno sobre a inflação: da Segunda Guerra Mundial à crise cambial (1939-1947) *
}

\author{
Patrick Fontaine ${ }^{* *}$
}

\begin{abstract}
Resumo
Esse artigo analisa a evolução e a controvérsia do pensamento brasileiro sobre a inflação, desde o início da Segunda Guerra Mundial até a Crise Cambial de 1947. Ao longo desse período, o debate se organiza entre dois polos opositores. De um lado, liberais, como Gudin e Carvalho, argumentavam ser o excesso de demanda, aquecida pelas encomendas das economias em esforço de guerra, a principal causa para a inflação. Do outro, desenvolvimentistas, como Simonsen, Almeida e Menezes, argumentavam haver na economia brasileira enormes excedentes de mão de obra a serem incorporados, e viam com bons olhos a internalização de processos industriais. A inflação seria resultado do contexto de exceção, que encarecia importados, e da insuficiência de crescimento da oferta interna. O debate tem seu clímax na definição de uma estratégia para conter a crise do balanço de pagamentos deflagrada pelo esgotamento das reservas internacionais, em 1947. Houve uma convergência entre autores liberais e desenvolvimentistas, quando ambos apoiaram a restrição de importações como solução para a crise. Essa solução, apesar de seu caráter intervencionista, foi a preferida por ambos os polos opositores, já que permitiria evitar eventuais desvalorizações do cruzeiro, que, naquele contexto, foram entendidas como potenciais agravantes do processo inflacionário. A aceitação de posturas intervencionistas por parte dos liberais abriu espaço para o florescimento e diversificação das análises sobre as particularidades do processo inflacionário brasileiro.
\end{abstract}

Palavras-chave: Inflação; Pensamento brasileiro; Anos 1940.

\section{Abstract \\ The formation of Brazilian modern thought on inflation: from the Second World War to the exchange rate crisis (1939- 1947)}

This article analyses the controversy and the evolution of the Brazilian thought on inflation, from the eruption of the Second World War to the 1947 exchange rate crisis. Throughout this period, the debate was organized into two opposing poles. On one side, liberals, such as Gudin and Carvalho, argued that excessive demand, increased by purchases from countries involved in the war effort, was the main cause of inflation. Developmentalists, such as Simonsen, Almeida and Menezes, on the opposite side, argued that the Brazilian economy had large workforce surpluses to be utilized, and saw the internalization of industrial processes as positive. The debate reached its climax with the definition of a strategy to contain the exchange rate crisis initiated by the depletion of foreign currency in 1947. Convergence between liberals and developmentalists took place, and both supported an administrative import license in order to control the commercial deficit that Brazil was increasingly experiencing. Both sides considered it a solution that could potentially solve the exchange crisis and, at the same time, avoid an inflationary shock, which could potentially result from a devaluation of the exchange rate. The liberals' acceptance of interventionist stances allowed for the flourishing and diversification of analyses on the particularities of the Brazilian inflationary process.

Keywords: Inflation; Brazilian thought; 1940s.

JEL B22.

* Artigo recebido em 29 de janeiro de 2018 e aprovado em 6 de fevereiro de 2019. Este trabalho contou com o financiamento da Capes e do CNPq, e com os comentários de Ricardo Bielschowsky, André Modenesi, Carlos Bastos, Pedro Fonseca, Angela Ganem e Victor Araújo. Devo agradecer a todos, sem responsabilizá-los por qualquer equívoco ou omissão.

** Professor Adjunto da Universidade Federal de Alfenas (Unifal), Alfenas, MG, Brasil. E-mail: patrick.fontaine@hotmail.com. ORCID: https://orcid.org/0000-0002-8639-122X. 


\section{Introdução}

Este artigo se propõe a analisar o pensamento sobre a inflação no Brasil, do início da Segunda Guerra Mundial, em 1939, até a Crise Cambial que se desencadeou em 1947. Tratase de um período marcado por um processo de reordenamento global associado ao conflito, no qual as autoridades e acadêmicos brasileiros perceberam uma oportunidade de exercer um papel mais destacado na economia mundial. Como resultado dessa percepção, houve uma crescente efervescência, circulação e consolidação de publicações ligadas à economia no Brasil, que foi chamada de "boom" dos Estudos Econômicos: "Nós testemunhamos agora uma corrida na organização de institutos, fundação de sociedades e faculdades de Economia, novas publicações econômicas e assim por diante" (Normano, 1944, p. 15).

As análises sobre a realidade econômica expressas no princípio dos anos 40, no entanto, se caracterizavam por um marcante ecletismo. Autores inspiravam-se em aportes de escolas de pensamento distintas com muita fluidez, o que pode ser explicado pela incipiência do estudo da economia no Brasil, ou pela dificuldade enfrentada em aplicar-se os aportes teóricos formulados no primeiro mundo à uma realidade subdesenvolvida (Fonseca, 2000). A maioria dos autores, mesmo dentre aqueles que rivalizavam, concordavam em apontar o sistema econômico brasileiro como particularmente distinto daqueles observados nos países centrais. Não havia, assim, uma clara associação às escolas tal como se apresentavam originalmente no contexto europeu e estadunidense, e os debates se organizavam em torno da identificação das causas e soluções para os problemas econômicos particulares enfrentados pela economia brasileira.

O debate com contornos mais bem-acabados, que vinha se desenrolando desde os anos 1930, estabeleceu-se em torno da necessidade, ou não, de planejamento estatal da economia (Teixeira; Maringoni; Gentil, 2010). Desde a Revolução de 1930 o Estado vinha assumindo as rédeas da economia, em paralelo com o New Deal de Roosevelt, e a discussão do planejamento tornou-se necessária para estabelecer os limites e possibilidades dessa atuação. Houve, então, como fruto dessa pauta, uma polarização entre autores liberais, representados por Gudin, e desenvolvimentistas (ou intervencionistas, como se convencionou chamar no período), representados por Simonsen ${ }^{1}$.

O cenário polarizado que se desenhou contrastava com a relativa hegemonia do pensamento liberal que havia sido a tônica do princípio do século XX (Mantega, 1984; Bielschowsky, 1988). O liberalismo brasileiro, que tinha as classes agroexportadoras como principal base social de sustentação, agia em defesa do livre-comércio, posicionando-se em contrário a políticas que privilegiassem o desenvolvimento industrial. $\mathrm{O}$ intervencionismo era

(1) "No Brasil essa problemática surge nos anos 30, e toma corpo principalmente com a polêmica travada na década de 30 entre dois personagens de maior destaque, tanto no plano teórico, quanto na vida político-econômica do país: o primeiro, Roberto Simonsen, empresário líder da Federação das Indústrias de São Paulo, defendendo o intervencionismo; e o segundo, Eugênio Gudin, professor de economia, diretor de empresas estrangeiras de serviços, defendendo o liberalismo" (Mantega, 1984, p. 26). 
capitaneado pelos ainda incipientes industrialistas, que se circunscreviam à emergente agenda do desenvolvimentismo ${ }^{2}$. Nessa controvérsia, o debate sobre inflação se tornou central para a argumentação de ambos os lados da oposição estabelecida, como se verá adiante.

De modo geral, o período compreendido entre 1939 e 1947 pode ser dividido em duas fases. Primeiro, o período coincidente com a Segunda Guerra Mundial (1939-1945), no qual o comércio mundial esteve parcialmente interrompido. Nesse contexto, a economia brasileira passou a acumular superávits comerciais e, consequentemente, reservas em dólares, já que as importações, mesmo que demandadas, não podiam realizar-se nos montantes demandados. As importações de máquinas, equipamentos e insumos foram dificultadas, mas, ao mesmo tempo, a economia brasileira teve de atender às encomendas dos países aliados para fomentar, com bens agrícolas e semimanufaturados, as economias em esforço de guerra. Na primeira parte do texto serão analisadas as percepções dos autores sobre os impactos desses condicionantes contextuais para a dinâmica interna de preços.

O período subsequente (1945-1947) corresponde à transição para a normalidade do comércio global, mas que implicou na emergência de uma severa crise cambial no Brasil, precipitada pela explosão do volume e dos preços das importações realizadas. A expectativa de um período de estabilidade monetária e cambial no pós-guerra se frustrou, e o esgotamento das divisas forçou um diálogo entre os analistas da economia brasileira, que precisaram encontrar uma solução para o problema cambial que ao mesmo tempo mantivesse sob controle a trajetória interna dos preços. Os contornos desse debate, bem como a solução adotada serão analisados neste texto.

\section{A controvérsia sobre inflação no contexto de guerra}

As condições econômicas dos primeiros anos da década de 1940 foram fortemente afetadas pelas interrupções e alterações dos fluxos comerciais geradas pela Segunda Guerra Mundial. Economias centrais dedicaram toda a produção interna ao esforço de guerra, interrompendo os fluxos de manufaturas que normalmente se fazia para a periferia e, ao mesmo tempo, demandavam, a preços crescentes, produtos alimentícios, outros bens primários e artigos semimanufaturados para abastecer as economias ao longo do conflito (Gudin, 1944; Carvalho, 1947).

Nesse contexto, a estrutura produtiva brasileira diversificou-se. Houve um forte aumento da produção manufatureira, como forma de atender à demanda interna, que deixou de

(2) “A questão principal das disputas teóricas e políticas relativas ao futuro dos países subdesenvolvidos foi, nos anos 40 e 50, a da conveniência da intervenção do Estado para estabelecer um novo padrão de crescimento. O principal ataque contra a doutrina dominante tinha como alvo os princípios do livre-comércio, ou seja, da eficiência da alocação de recursos a nível interno e externo, por meio dos mecanismos de mercado. Este ataque objetivava dar suporte a medidas governamentais, em particular ao planejamento e ao protecionismo, que eram vistos como meios de se alcançar industrialização rápida e eficiente e, consequentemente, de se alterar o curso da história dos países subdesenvolvidos” (Bielschowsky, 1988, p. 12). 
contar com a oferta externa, devido à interrupção do fluxo de importações ${ }^{3}$. Ao mesmo tempo, o país atuava fornecendo insumos sobretudo para os EUA e para a Inglaterra, e interessava aos aliados que os produtos chegassem no maior nível de processamento possível, como forma de poupar tempo de trabalho nas já sobrecarregadas estruturas produtivas internas. Como resultado, a participação dos produtos manufaturados na pauta de exportações e no total da renda brasileira aumentou progressivamente. Bens agropecuários passaram a ser exportados após alguma etapa de processamento industrial ${ }^{4}$. O quantum das exportações se retraiu ao longo do conflito, mas os valores mais que compensaram essa queda. O mesmo movimento ocorreu com as importações, que se retraíram em quantum, com elevações no valor em contrapartida. O aumento do valor das importações, no entanto, foi muito inferior ao das exportações, o que se traduziu em amplos e sucessivos superávits comerciais ao longo do conflito ${ }^{5}$.

Esse contexto, de florescimento industrial e de acumulação de superávits, penetrou então no debate econômico. As instâncias de poder absorveram em seu discurso um tom industrialista, que até então teria estado ausente, posicionando-se em favor de medidas próindustrialização ${ }^{6}$ :

O problema básico da nossa economia estará, em breve, sob novo signo. País semicolonial, agrário, importador de manufaturas e exportador de matérias-primas poderá arcar com as responsabilidades de uma vida industrial autônoma, provendo as suas urgentes necessidades de defesa e aparelhamento. Já não é mais adiável a solução. Mesmo os mais empedernidos conservadores agrários compreendem que não é possível depender da importação de máquinas e ferramentas... (Getúlio Vargas num discurso em Volta Redonda, em 1943, citado em Bielschowsky, 2000, p. 63).

Liberais, por sua vez, articulados em torno de Eugênio Gudin, entendiam que o crescimento da indústria seria reflexo de distorções de caráter degenerativo da estrutura produtiva brasileira, provocada pela excepcionalidade contextual do conflito mundial. A demanda externa aquecida e a impossibilidade de importar teriam deslocado capacidade produtiva dos setores tradicionais, de maior produtividade, para setores novos e menos eficientes. Nessa perspectiva, o desenvolvimento industrial seria então um resultado indesejado

(3) A partir de 1939 os fluxos de importação e exportação começam a se retrair em quantidade. Os volumes físicos de importação e exportação passam de, respectivamente, 4.874 e 4.183 toneladas em 1939, para 3.842 e 2.671 toneladas em 1944. A movimentação de cabotagem nos portos de Santos e Rio de Janeiro cai significativamente, cerca de 44,6\% na saída, e $43 \%$ na entrada, entre 1941 e 1943 (Carvalho, 1947, p. 58, 60).

(4) A exportação do algodão em rama deu lugar à exportação de tecidos de algodão, e a de carnes frigorificadas foi substituída pela de carnes em conserva, por exemplo (Ver Carvalho, 1947).

(5) O valor das exportações passou de 5,1 bilhões de cruzeiros, em 1938, para 12,2 bilhões em 1945, e o preço de uma saca de café passou de 134 para 281 cruzeiros, entre 1938 e o primeiro semestre de 1943 . O valor das importações, por sua vez, foi de 5,2 bilhões em 1938 para 8,6 bilhões de cruzeiros em 1945 (Carvalho, 1947, p. 56-58).

(6) 'Só as mentalidades impermeáveis aos fatos podem acreditar ainda na validade dos princípios do 'laissez-faire' econômico e nos seus corolários políticos. O livre jogo das forças sociais, no estágio de evolução que atingimos, é a anarquia pura e simples. Esta verdade, cabalmente confirmada pelas punições da guerra às grandes potências mundiais, torna-se de maior evidência em relação aos povos como o nosso, em plena fase de crescimento e expansão" (Vargas, Getúlio. Discurso de 1944, citado em Mantega, 1984, p. 29). 
do mau funcionamento do livre mercado num contexto de guerra. A inflação, que se acelerava, seria a manifestação monetária da perda de eficiência do sistema:

Tratando-se então de uma guerra mundial, como a atual, de proporções nunca previstas, a repercussão é também mundial, se bem que o fenômeno tenha as mesmas causas básicas. O deslocamento de milhões de trabalhadores, de seus afazeres usuais para fins bélicos, das fábricas às frentes de combate, fatalmente produzirá o desequilíbrio acima referido [a inflação], agravado por um poder aquisitivo maior resultante de salários maiores decorrentes não só da elevação das remunerações como do aumento de tempo de serviço (Aranha, 1945, p. 40).

A crítica liberal, que sustentava sua argumentação com base na noção de vocação agrária brasileira ${ }^{7}$, interpretou a inflação crescente como fruto da alocação ineficiente de recursos na indústria. $\mathrm{O}$ contexto permitiu essa interpretação, já que a aceleração dos preços e o crescimento mais veloz do segmento industrial, foram fenômenos que ocorreram em paralelo, sobretudo a partir de 1941, e interpretados por liberais como correlatos. Num país vocacionado para a agricultura, qualquer deslocamento de escassos recursos para a indústria seria ineficiente, e se manifestaria, cedo ou tarde, como inflação. Nesse contexto, Gudin apontava as políticas de promoção de obras públicas ${ }^{8}$, o deslocamento de capacidade produtiva para atendimento das demandas por importações dos países em guerra, e a impossibilidade de importar o que internamente se demandava ${ }^{9}$, como os principais fatores que superaqueciam a economia, escasseando a disponibilidade de fatores de produção ${ }^{10}$ :

Quando em uma região ou em uma nação, a atividade econômica já atingiu a um ponto em que, praticamente, todos os fatores de produção estão empregados, a iniciativa de novas atividades, venha ela do Governo ou de particulares, terá o efeito de fazer subir os preços por força da procura adicional de fatores de produção já empregados, mas não o de aumentar a produção, porque o desvio de fatores de produção de uma para outra atividade só permite aumentar uma produção em detrimento de outra (Gudin, 1946, p. 1).

(7) Disponibilidade de terras, fertilidade do solo, regularidade topográfica, etc. Para mais sobre o debate ver Bielschowsky (1988).

(8) "É no setor de investimentos públicos que se verifica considerável atividade. Além das obras militares executadas pelos Governos Brasileiro e Americano, indispensáveis ao curso da guerra, inúmeros e vultosos são os empreendimentos públicos em todas as regiões do país: novas estradas de ferro e de rodagem em vários Estados, grandes remodelações de traçado na Central do Brasil, Volta Redonda, Rio Doce, Usinas de Macabu, Baixada, Companhia da Borracha, Estrada de Ferro para a Bolívia, Palácios para Ministérios e Institutos Paraestatais, Avenidas, etc., etc.” (Gudin, 1944, p. 29-30). Carvalho compartilha dessa leitura, ressaltando o fato de que em condições excepcionais o governo tinha maior autoridade para ampliar seus déficits (Carvalho, 1947, p. 49).

(9) "Não produzimos canhões e munições, mas produzimos café, algodão, borracha, minérios, etc. que exportamos para os Estados Unidos e a Inglaterra, sem que desses países possamos comprar mercadorias correspondentes. (...) os que produzem café, algodão, os tecidos, a borracha, etc. exportados recebem rendimentos em pagamento de seu trabalho, mas as mercadorias correspondentes não são substituídas por outras mercadorias de importação. E é assim que se verifica o desequilíbrio de excesso de rendimentos em relação às mercadorias a serviço disponíveis" (Gudin, 1944, p. 9).

(10) "Acrescente-se o desfalque de mão de obra produzido pelas convocações para o serviço militar; junte-se a necessidade de atender à produção de emergência para a substituição de produtos normalmente importados, inclusive o carvão de madeira e a lenha, e o que causa admiração é que ainda reste um pouco de mão de obra para produzir milho, arroz, feijão, leite, etc.” (Gudin, 1945, p. 30). 
$\mathrm{O}$ argumento de que haveria perda de eficiência na passagem de segmentos agropecuários para a indústria, sustentado por Gudin, era alimentado, naquele contexto, pelo fato dos setores de exportação da economia brasileira serem "verdadeiras ilhas de alta produtividade, em forte contraste com o atraso do restante do sistema produtivo" (Bielschowsky, 1988, p. 19). As fontes adicionais de demanda e a subjacente absorção de mão de obra no setor industrial, teriam então gerado uma situação de sobre-emprego, na qual o nível de atividade estaria operando acima da capacidade produtiva do sistema, implicando num leilão por mão de obra, e preços crescentes. Essa análise parte do pressuposto de que não haveria mão de obra sobressalente disponível ${ }^{11}$, e, assim, o deslocamento de trabalho para a indústria só poderia ocorrer em detrimento do emprego nas lavouras, que abasteciam o mercado interno, e com aumento do custo do trabalho:

Salvo em um ou outro ponto isolado do país, a existência de um hiper-emprego de grande intensidade na atual conjuntura da Economia Brasileira salta aos olhos, mesmo de quem não quer ver. $\mathrm{O}$ agricultor que precisa de braços para o trato de suas lavouras não os tem; o industrial que precisa de maior número de operários não os encontra desempregados; (...). E os preços sobem ininterruptamente. E, como sempre, quando há hiper-emprego, decaem a disciplina e a produtividade do operariado (Gudin, 1946, p. 2).

A análise de Gudin encontrou ressonância no texto de Fernando Mibieli de Carvalho, A Inflação Brasileira, que escreveu ao Observador Econômico e Financeiro como funcionário do Fundo Monetário Internacional (FMI ${ }^{12}$. Carvalho argumentava que os crescentes preços de produtos exportáveis brasileiros teriam atraído fatores de produção para estes setores, deixando em segundo plano setores tradicionais. O aumento dos custos de importação de trigo e combustíveis, foram incorporados às explicações para a aceleração dos preços, mas seriam secundários num contexto de superaquecimento da economia interna:

Os altos preços obtidos no comércio de exportação pelos produtos minerais, os da indústria extrativa agrícola e as manufaturas (tecidos, pneumáticos e câmaras de ar, manufaturas de couros e peles e produtos farmacêuticos), fizeram com que a nossa vida rural sofresse uma verdadeira revolução, abandonando as suas populações o trabalho agrícola pela extração de pedras preciosas, mica, cristal de rocha, carbonados, diamante industrial e outros minerais estratégicos, ou demandando as capitais dos Estados e os grandes centros industriais de São Paulo e Distrito Federal, em busca de emprego nas fábricas (Carvalho, 1947, p. 53).

Ambos Gudin (1944) e Carvalho (1947), além de criticar a suposta sobrecarga exercida sobre os meios de produção, sustentaram a ideia de que os superávits comerciais acumulados

(11) Bielschowsky entende que o conceito de pleno-emprego é fundamental para a consistência interna da argumentação de Gudin, em toda sua obra: "A hipótese central de sua argumentação é a da existência de pleno-emprego na economia brasileira. Era este um ponto indispensável à consistência de suas formulações” (Bielschowsky, 2001, p. 93). O autor chega inclusive a cunhar o conceito de arqui-hiper-emprego: "Grande parte do nosso desequilíbrio econômico provém exatamente da hipertrofia de nossa atividade no setor dos investimentos, relativamente ao setor das mercadorias de consumo. Os problemas que mais preocupam os economistas são os do desemprego nas épocas de depressão e do excesso de emprego nas épocas de inflação. Nossa situação é de arqui-hiper-emprego" (Gudin, 1944, p. 74).

(12) O autor foi consultor jurídico do CNPq a partir de 1951, e publicou textos relacionados à questão migratória. 
ao longo da guerra teriam contribuído para a evolução de preços. Os saldos positivos em dólares (e outras divisas) eram esterilizados com moeda local, gerando um aumento da base monetária. Assim, enquanto cresciam as reservas internacionais, crescia em paralelo a base monetária, já que o governo precisava emitir cruzeiros para comprar os dólares resultantes do saldo exportador:

No nosso caso, o excesso de rendimentos, isto é, a inflação, provém do dinheiro que o Banco do Brasil é obrigado a desembolsar (e a emitir) para comprar aos exportadores as suas letras de exportação de café, cacau, tecidos, óleos, etc. Em época normal, o Banco compra essas letras aos exportadores e as vende, quase ao mesmo tempo, aos importadores. O dinheiro sai por uma porta e entra pela outra. Agora não. O dinheiro sai para os exportadores e não volta pela mão dos importadores. Fica em circulação, saltando de galho em galho [...] e aumentando os preços em todos os lugares onde pousa (Gudin, 1944, p. 9-10).

A excepcionalidade da guerra impedia as divisas de serem gastas em importações, e a forma como se conduzia a esterilização de excedentes do comércio exterior seria então uma das raízes do processo inflacionário. Como aponta Gudin, “[e]xportar sem importar é acumular reservas. O mal está em sermos obrigados, para esse fim, a emitir grandes quantidades de papelmoeda, com efeitos desastrosos para nossa economia interna. [...] O problema consiste em absorver as emissões feitas para a exportação" (Gudin, 1944, p. 23).

Bulhões e Kingston (1947), e Kershaw ${ }^{13}$ reforçaram a argumentação de Gudin e Carvalho, apresentando dados de uma grande expansão da base monetária, entre 1941 e 1946, que teria ocorrido, sobretudo, via emissões feitas para esterilizar os superávits comerciais. Mas, ao argumento básico de Gudin, os autores adicionaram a ideia de que o contexto inflacionário teria proporcionado maior liberdade para que produtores aumentassem os preços de venda numa velocidade superior ao aumento dos salários, aumentando suas margens de lucro. Estaria em curso um perverso mecanismo de expansão monetária, alavancado por superávits comerciais, no qual produtores absorviam parcela cada vez maior da renda total, em detrimento dos trabalhadores, já que a autonomia para reajustar preços era significativa e escamoteada pela confusão do contexto inflacionário (Bulhões; Kingston, 1947).

Como propostas de solução para o problema da inflação, Gudin (1944, 1945, e 1946), Carvalho (1947) e Bulhões e Kingston (1947) propuseram o contingenciamento das despesas públicas, a emissão de "Obrigações Especiais" para absorção de divisas oriundas dos superávits comerciais, e a criação de um orçamento separado para as inevitáveis despesas de guerra. As duas primeiras medidas incidiriam diretamente nos aludidos efeitos de expansão da base monetária e reduziriam a pressão exercida pelo governo sobre a estrutura produtiva. A terceira

(13) "Durante os anos de guerra, o excesso de exportação foi tremendo, pois muitas nações compraram febrilmente para necessidades de guerra, mas venderam relativamente pouco. Para os anos de 1931-40, o excesso de exportação no Brasil atingiu a média de 533 milhões de cruzeiros. Essa média para os anos de guerra 1941-45 foi cinco vezes maior e em 1946 ultrapassou os 4 bilhões de cruzeiros. Nisto reside a explicação da grande inflação no Brasil. As rendas criadas pelas exportações não puderam ser aplicadas na aquisição de utilidades e os créditos em cruzeiros assim obtidos competiram com outros no limitado suprimento de utilidades, forçando a alta de preços" (Kershaw, 1948, p. 46). 
medida sinalizaria o ordenamento das contas públicas. Além disso, Bulhões e Kingston se mostraram preocupados com o direcionamento da produção nacional, que seguia praticando preços elevados, voltados para o mercado externo, mesmo após a guerra:

A influência da exportação não se faz sentir mais na expansão monetária, pois, com o aumento da importação já não presenciamos os inconvenientes verificados em anos anteriores. O grande problema da exportação reside, neste momento, na manutenção dos preços dos produtos em nível superior à capacidade dos consumidores nacionais (Bulhões; Kingston, 1947, p. 25).

Visando reduzir os preços praticados pelos produtores nacionais, os autores propuseram a categorização dos produtos, separando aqueles tipicamente voltados para o mercado externo e os potencialmente consumidos internamente ${ }^{14}$. Produtos de exportação teriam os preços submetidos a monitoramento e, em momentos de alta, os excedentes seriam absorvidos por um fundo público, que compensaria as perdas em momentos de baixa. Os produtos de consumo interno teriam a exportação restrita aos casos de preços compatíveis com os praticados internamente. Esses mecanismos funcionariam como um imposto regulador de preços, que absorveria as flutuações geradas no mercado internacional e priorizaria o abastecimento interno independentemente da rentabilidade do comércio exterior. O que se nota, implícito na proposta, é o diagnóstico de que os choques externos estavam perturbando o funcionamento do mecanismo de preços, e que cabia ao Estado proativamente absorvê-los para evitar seus desdobramentos. Os autores propuseram ainda a incidência de um imposto sobre os lucros "extraordinários" da indústria ${ }^{15}$, e o encaminhamento de pessoas desocupadas a núcleos agrícolas organizados pelo Estado para evitar seu emprego em indústrias ineficientes ${ }^{16}$. O conjunto de medidas propostas protegeria o mercado interno das influências externas nocivas, e permitiria a canalização dos recursos para os setores desejados:

Com essa ordem de medidas seria suprimido o incentivo ao acréscimo de lucros, em função do aumento de preços; seria fomentada a produção de gêneros alimentícios; formar-se-ia uma reserva, embora um tanto tardia, das receitas extraordinárias na exportação, de molde a proporcionar recursos para minorar as perdas oriundas da violência das primeiras quedas de preços; forçar-se-ia o declínio de preços internamente, antes de se verificar a baixa, no comércio internacional; manter-se-ia preparada a política de crédito para regular a redução de preços, incluindo-se nessa política a suspensão do congelamento de reservas, conforme é implicitamente subentendido na atual legislação sobre os lucros extraordinários (Bulhões; Kingston, 1947, p. 28).

(14) "No primeiro [grupo], considerar as mercadorias caracteristicamente de exportação; sobre esses produtos adotar a arrecadação de parte da receita de acordo com o aumento de preços, mormente se o cruzeiro vier a ser depreciado em relação ao dólar, para a constituição de um fundo destinado a subvencionar a exportação, quando futuramente se presenciar uma redução mais acentuada de preços, nos mercados externos. No segundo grupo, considerar as mercadorias nitidamente de consumo nacional e que só passaram a figurar na exportação por força da guerra; em relação a esses produtos forçar a baixa de seus preços permitindose a exportação tão somente depois de verificar uma redução de preços” (Bulhões; Kingston, 1947, p. 27).

(15) A ideia de lucros extraordinários está associada a um contexto de ausência de concorrência e proteção aduaneira.

(16) Nas palavras dos autores: "Evitar o amparo de produtores marginais na indústria, promovendo o Governo o encaminhamento dos desempregados aos núcleos agrícolas, ainda mesmo que tais despesas tenham de ser feitas por meio de emissão de papel moeda" (Bulhões; Kingston, 1947, p. 28). 
Num contexto de aceleração inflacionária, as propostas de Bulhões e Kingston (1947) tiveram caráter pouco ortodoxo, propugnando elevado grau de intervenção sobre a estrutura produtiva. Os autores entendiam que um pacote de medidas exclusivamente monetárias não seria suficiente para conter a evolução dos preços, num contexto tão particular quanto aquele que enfrentavam, e que a depressão era indesejável qualquer que fosse o cenário: "Essas sugestões apresentam, a nosso ver, a vantagem de constituírem um conjunto harmônico de medidas monetárias e amonetárias como programa de combate à inflação e de cautela contra a depressão" (Bulhões; Kingston, 1947 p. 29).

De maneira geral, as propostas de Gudin, Carvalho e de Bulhões e Kingston, foram representadas nos Anais do I Primeiro Congresso Brasileiro de Economia, de $1943^{17}$, realizado no Rio de Janeiro, que abarcou as mais variadas vertentes ideológicas. No entanto, a posição de Bulhões e Kingston, isoladamente, talvez deva ser entendida como intermediária no espectro entre intervencionismo e liberalismo, enquanto Gudin e Carvalho representam o liberalismo. Intervencionistas também tiveram espaço no Congresso, e Roberto Simonsen exercia o contraponto a Gudin e Carvalho. A força da argumentação do autor, bem como da maioria dos autores que se opunham à ideia de vocação agrária, estava na defesa do potencial de desenvolvimento portado pela indústria, algo que defendia desde os anos 1930:

Inventaram, para uso do Brasil, o termo "indústria artificial" que passou a ser rifão nacional. Em tese geral, num país populoso como o Brasil e com os nossos recursos naturais, não existem "indústrias artificiais". Naturalmente, existem em alguns países industrias muito especializadas cuja locação mais favorável, a prática e a tradição já se estabeleceram e a seleção das invenções e dos aparelhamentos técnicos já se consagraram. Os Estados Unidos favorecem a indústria da torrefação do café dificultando a importação do café em pó; a Inglaterra favorece a refinação do açúcar, haverá indústrias mais artificiais para aquelas adiantadas nações do que essas a prevalecer o critério brasileiro? A Inglaterra, a Itália e mesmo a Alemanha não importam enorme quantidade de matérias-primas para as suas indústrias? (Simonsen, 1930, p. 42).

Simonsen argumentava, com base em List e Manoilescu, que seria necessário proteger a indústria nascente até que ganhasse escala e projeção global, afim de desenvolver o potencial manufatureiro brasileiro, e compilou os "fundamentos científicos do protecionismo" (Simonsen, 1934, p. 45). Dentre os princípios, estava a ideia de que a disseminação do progresso técnico se daria com maior facilidade nos setores industriais, e que a indústria

(17) Algumas dentre as medidas propostas: "O I Congresso Brasileiro de Economia, reconhecendo a indiscutível existência de inflação no Brasil, recomenda: a redução dos encargos, mediante restrição de despesas adiáveis, na União, Estados e Municípios; que, como medida complementar de combate à inflação, sejam as despesas públicas orientadas no sentido da maior utilidade total para o País; que as despesas de guerra sejam objeto de um orçamento especial, cujos recursos extraordinários sejam providos notadamente pela emissão de Obrigações de Guerra e pelo aumento temporário de impostos; que a exportação de artigos de primeira necessidade seja condicionada ao imprescindível suprimento do mercado interno; que sejam criados tipos padronizados de artigos de consumo popular, de preços acessíveis às classes menos favorecidas" (Anais do I Congresso Brasileiro de Economia, 1944, p. 164). 
tenderia a ter, em países atrasados, produtividade muito similar à verificada em países desenvolvidos ${ }^{18}$, o que permitiria uma interação competitiva no mercado global.

No que concerne mais especificamente à inflação, Simonsen refutava a ideia de industrialização inflacionária, apoiando-se no argumento de aumento da produtividade ${ }^{19}$ (Simonsen, 1931). Entendia a moeda como veículo das transações ${ }^{20}$, que deveria acompanhar, em volume, a expansão da produção, duvidando de seu potencial inflacionário per se. Reputava, aliás, à "baixa elasticidade do meio circulante ${ }^{21}$ " um dos principais problemas da economia brasileira. A expansão monetária tardaria a reagir ao crescimento da produção, prejudicando o crescimento econômico:

A causa fundamental dos entraves ao nosso desenvolvimento econômico reside no defeito congênito do nosso meio circulante e na insuficiência do nosso aparelhamento de crédito, que além de não amparar nossa produção, nos deixa ainda indefesos contra as repercussões das crises externas (Simonsen, 1930, p. 41).

Quanto à inflação no período de guerra, as razões estariam associadas às dificuldades enfrentadas pela situação de exceção, que encarecia as importações, mas também a uma certa estagnação do setor agropecuário, que não teria se expandido o suficiente ao longo do conflito, ao passo que a população seguia crescendo. Concordou com Gudin ao afirmar ser a transferência de mão de obra de setores voltados ao mercado interno para setores exportadores, uma das causas do aumento de preços:

É impressionante (...) a estagnação que se observa em muitas atividades primárias, principalmente em relação à agricultura de alimentação. Os artigos alimentícios há dez anos que se mantém numa produção total em torno de 18,5 milhões de toneladas. Com o aumento da população, com as exportações realizadas com as dificuldades de transportes, houve, de fato, uma apreciável diminuição na produção virtual da alimentação, o que explica, em parte, a carestia com que defrontamos, em relação aos gêneros alimentícios. As indústrias extrativas de materiais estratégicos e a agricultura de produtos ricos, tais como o algodão, menta, seda natural, atraíram os braços disponíveis da lavoura, em prejuízo da produção de artigos de primeira necessidade. Contribuíram, ainda, para desestimular esse ramo da agricultura, a carência de transportes e os tabelamentos (Simonsen, 1945, p. 91).

(18) "Quanto mais atrasado é um país, menor é a produtividade das classes agrícolas em comparação com a produtividade dos países industriais; no entanto, nesses mesmos países atrasados a produtividade industrial em relação aos países adiantados não oferece tão grandes condições de inferioridade" (Simonsen, 1931, p. 47).

(19) "A ignorância dos nossos problemas técnicos faz com que muitos de nossos patrícios se orientem para a destruição, ao invés de para um trabalho construtivo e de amparo à nossa produção. Um dos 'leit motivs' prediletos contra a indústria é que ela vem trazendo um encarecimento progressivo da vida pelo regime de protecionismo em que vivemos" (Simonsen, 1931, p. 50).

(20) "Seria incapaz de confundir poder econômico com moeda. A moeda é apenas um veículo da circulação das riquezas" (Simonsen, 1934, p. 37).

(21) "A unanimidade dos autores modernos e dos peritos financeiros, atribui à elasticidade da moeda quase tão grande importância como à sua estabilidade. (...) Sabemos que a moeda inglesa é rígida; mas além da Inglaterra estar em situação excepcional de país capitalista, constituindo o rendimento de seus capitais no estrangeiro uma das suas maiores fontes de renda, fazem todos os autores modernos notar que o Bank Act da Inglaterra é tão perfeito que, sempre que há uma crise... o Parlamento vota uma medida de exceção. O Bank Act não funciona em crise" (Simonsen, 1930, p. 22). 
Simonsen, apesar de afirmar haver distúrbios de preços causados pelo contexto de exceção e pelo excesso de demanda por trabalho, acreditava que a solução para o problema da inflação passava por uma industrialização progressiva, inclusive no segmento agropecuário, como forma de conter preços através da expansão da oferta. Esteve por trás da Carta Econômica de Teresópolis, fruto da conferência de representantes das classes produtoras na cidade serrana, em 1945, um dos fóruns onde expressou-se mais sólida e enfaticamente uma proposta de combate à inflação em linha com a defesa do desenvolvimento industrial ${ }^{22}$. $\mathrm{O}$ diagnóstico elaborado na Carta é híbrido, e a restrição do meio circulante e dos gastos públicos apareceu entre as propostas, mas o cerne do documento está na promoção da atividade produtiva como forma de atender à demanda cada vez maior. Nessa linha, o texto é explícito ao sugerir "o estímulo da produção para efeito de corrigir a deficiência de bens, provocando, assim, a absorção do excesso do poder aquisitivo existente e concorrendo, também, para a redução do custo de vida" (Carta Econômica de Teresópolis, 1945, p. 12).

O estímulo à produção passaria pela criação de um mecanismo de seleção de créditos prioritários $^{23}$ (ou seletivos), aos quais empreendimentos entendidos como importantes para a expansão da capacidade produtiva teriam acesso, reduzindo a pressão sobre a capacidade instalada: "As inversões de capital devem ser sujeitas ao seletivo de crédito, de modo que não concorram para agravar a inflação, sendo ampliadas convenientemente as operações normais de crédito sob essa orientação" (Carta Econômica de Teresópolis, 1945, p. 12). A expansão do crédito através do mecanismo seletivo visava evitar um estímulo monetário exagerado, garantindo a expansão daquelas atividades entendidas como estratégicas para o crescimento e o desenvolvimento econômico. A carta ressaltava, assim como fizeram Bulhões e Kingston, a necessidade de se subordinar a política monetária ao objetivo do desenvolvimento econômico: "É princípio reconhecido pelas classes produtoras a subordinação da política monetária à política econômica geral de fomento das atividades produtivas, e à ampliação do capital nacional" (Carta Econômica de Teresópolis, 1945, p. 12).

Cabe lembrar que a delegação brasileira em Bretton Woods, em 1944, defendeu posição similar sobre o financiamento do desenvolvimento industrial e da mecanização da agricultura $^{24}$. Havia a esperança de que o governo pudesse fomentar a produção com o apoio de empréstimos de Estado a Estado (Barreiros, 2009), esperança essa que se mostrou infundada no pós-guerra. Outra esperança frustrada foi a de que o FMI pudesse operar como garantidor

(22) "Representa essa conferência das classes produtoras para o Brasil uma revolução na sua estrutura econômica, política e social, de muito maior alcance do que a abolição dos escravos, em 1888, ou a proclamação da República, em 1889. Uma nova era de progresso e de vida intensa foi declarada ali. A transição do Brasil de país agrário para nação industrial ficou, indelevelmente, assinalada nas discussões travadas durante a Conferência" (Diniz, 1945, p. 99).

(23) "Recomenda-se a criação de bancos hipotecários e de crédito rural, que atendam às necessidades de crédito a longo prazo e juros módicos das atividades agropecuárias. Assim, também, a de bancos de crédito industrial especializado, de forma a atender às necessidades de expansão das instalações e das atividades industriais" (Carta Econômica de Teresópolis, 1945, p. 12).

(24) "Concluíam os técnicos brasileiros que o atendimento da demanda por alimentos necessitaria de 'intensive mechanization of agriculture', na medida em que a elevação do emprego do fator trabalho no campo não seria possível dado que [because a] large section of men has entered the armed forces of [Brazil], as well as the amount of men absorbed by the war industries, in the intensive mining regions of strategic products, in the rubber extraction in the Amazon, in substante, in the provision of labor for war industries and essential public works of a military and strategic character" (SC.1944.05.08.mf.dg - II -26, 1944, apud Barreiros, 2009, p. 556). 
de liquidez para as transações internacionais ${ }^{25}$, o que evitaria as dificuldades com moedas inconversíveis, além da institucionalização de instrumentos para contornar os impactos das oscilações da economia global sobre a estrutura produtiva brasileira ${ }^{26}$.

Dentre os desenvolvimentistas do período, Rômulo de Almeida pode ser destacado como aquele que expressava a posição que mais destoava da defendida por Gudin. O autor apresentou argumentos sobre o problema inflacionário na sua participação na Conferência Internacional de Comércio e Emprego, ocorrida em Londres entre outubro e novembro de 1946. O relato de Almeida, publicado em janeiro de 1947, deu ênfase às ideias e argumentos de "economistas indígenas" que afirmavam existir, no Brasil, enormes contingentes de mão de obra subempregada, ou empregada na subsistência:

[Há] desemprego de recursos naturais relacionado com o desemprego qualitativo, ou subemprego, da mão-de-obra (embora se declare o "hiperemprego quantitativo"), o qual é aspecto permanente ou a própria crise da nossa economia, pondo-o em relevo como fator para o comércio mundial (Almeida, 1947, p. 40).

Em outras palavras, haveria no país expressivos excedentes de fatores de produção, tanto de trabalho quanto de matéria-prima e terras, ainda passíveis de exploração. O contraste com o que vinha argumentando Gudin - que transparecia ter em mente a inadaptabilidade de determinados contingentes populacionais ao trabalho formal - é marcante. Almeida enaltecia a necessidade de "pleno emprego qualitativo", transferindo a população dedicada a atividades de subsistência para setores modernos, mais produtivos. A proposta encontrou eco em outras comitivas, sobretudo na da Índia, que experimentava fenômeno similar, mas terminou sendo repudiada pela comitiva estadunidense, como sendo uma tentativa de se "exportar desemprego" (Almeida, 1947).

Ainda na Conferência do Comércio, foram discutidas medidas para estabilizar os preços de artigos alimentares e agrícolas "tendo em vista não só curar, mas prevenir com antecedência os desequilíbrios na produção, nos mercados e nos preços, dar garantias aos importadores e conseguir abundância alimentar" (Almeida, 1947, p. 45), repetindo as demandas da delegação brasileira que esteve em Bretton Woods ${ }^{27}$, dessa vez com apoio da comitiva inglesa. Foram propostos mecanismos como escalas de preços básicos, fixando os

(25) "Torna-se indispensável criar organizações internacionais onde se coordene a política monetária relativamente ao comercio mundial e se orientem as correntes de capital de uns para outros países. Não se poderá contar com um mundo melhor sem alvitrar uma instituição permanente de reequilíbrio dos balanços de pagamento por meio de uma cooperação sistematizada entre as nações " (Bulhões, SC.1944.05.08.mf.dg - II-13, 1944: 16, apud Barreiros, 2009, p. 534).

(26) "A subordinação dos fatores internos aos fatores internacionais submete a moeda e o crédito a influências externas e torna impossível a orientação governamental da economia, necessária para evitar as depressões [...] O mecanismo de autorregulação da balança comercial de pagamentos somente pode funcionar em condições especiais, incompatíveis com a presente rigidez das estruturas de preços e salários" (Souza Costa, SC.1944.05.08.mf.dg - II-23, 1944, apud Barreiros, 2009, p. 535).

(27) "Os delegados do Brasil [...] pleitearam [...] o planejamento para a fundação de instituições voltadas para 'manter a regularização da oferta' de bens agrícolas no mercado internacional. Alegava a representação brasileira que o emprego e a estabilidade do sistema poderiam ser severamente abalados por "fluctuations in primary products resulting from climatic or other factors, with a resulting disequilibrium in relative prices capable of endangering the whole price structure" (SC.1944.05.08.mf.dg - II-13, 1944, p. 40), e que portanto o mercado de bens primários deveria ser protegido por um aparato institucional multilateral similar ao utilizado para o mercado de câmbio" (Barreiros, 2009, citando Souza Costa, p. 554). 
máximos (garantia dos consumidores) e os mínimos (dos produtores) e estoques reguladores (buffer stocks). Para o caso da persistência crônica de excedente, foi proposto um esquema regulatório que limitaria a produção e melhoraria a distribuição nos mercados e sugeriu-se o estabelecimento de contratos de longo prazo, que teriam a função de assegurar estabilidade à produção de gêneros perecíveis.

Outro tema abordado na conferência foi o controle direto de preços. Havia uma preocupação com a maneira como reagiriam os preços após a remoção dos controles vigentes nos EUA, e que haviam se tornado comuns no mundo ao longo do conflito. No Brasil, as primeiras iniciativas surgiram em $1934^{28}$, mas se intensificaram durante a guerra, através do decreto-lei n. 4750 de setembro de $1942^{29}$. O decreto criou a Coordenação de Mobilização Econômica, que tinha como função empenhar todos os recursos produtivos para os esforços de guerra, evitar a especulação, sobretudo num contexto de exceção, e garantir o suprimento de bens essenciais à população (Cytrynowic, 2000, p. 247). A ideia de controlar diretamente preços gozava de certa legitimidade ${ }^{30}$, mas a eficácia dos mecanismos era questionada ${ }^{31}$, e há relatos sobre como era fácil contorná- $\operatorname{los}^{32}$.

(28) O decreto n. 24150, de 20 de abril de 1934, estabelecia as condições para renovação de contratos de aluguel comercial, que impedia a majoração arbitrária dos mesmos: "Os aluguéis comerciais e industriais, no que tange às renovações de contrato, passaram a ser regidos por lei a partir de 1934, com a fixação de condições para a retomada dos imóveis por parte dos locadores, o estabelecimento de rotinas judicias para a realização de perícias que determinariam os novos valores locativos e a abertura da possibilidade de revisão daquele valor em decorrência da modificação das condições econômicas do lugar. A extensão destas normas aos imóveis residenciais ocorreu em 1946. Em poucos casos bem definidos, poderia o locador rescindir a locação, tendo sido autorizados aumentos para os alugueis em vigor, em função da antiguidade da locação. A este decreto-lei seguiram-se continuamente novos tetos legais que só vieram a se substancialmente alterados em 1964: a Lei n. 1.300, de 28 de dezembro de 1950 , por exemplo, estabeleceu em seu artigo $3^{\circ}$ que os alugueis residenciais em vigor não poderiam sofrer qualquer aumento, restrição esta que se aplicaria a qualquer situação contratual” (Mata, 1980, p. 914).

(29) "Em 1942, surgiram as primeiras medidas restritivas ao aumento dos aluguéis de prédios residenciais, que foram congelados aos níveis de dezembro do ano anterior. Logo após, foi estendido esse regime aos prédios comerciais em geral, cujos aluguéis, quando sujeitos a renovação de contrato de locação, podiam sofrer o acréscimo legal de $20 \%$ sobre o aluguel cobrado em 1941. Já então, o pagamento de luvas era o processo usual no reestabelecimento do equilíbrio entre oferta e procura" (Conjuntura Econômica, 1950b, p. 38).

(30) "Os centros mais esclarecidos das Classes Produtoras não tardaram a reconhecer que urgia o aviamento de um remédio específico para a moléstia, e este só podia ser, senão a baixa imediata dos preços, pelo menos o seu congelamento, com vantagens, pois o reestabelecimento do suspirado equilíbrio só por si já representará reparação muito mais importante para todos aqueles que compreendem a natureza de certas leis elementares de economia” (Editorial Digesto Econômico, 1945, p. 13-14).

(31) "A não limitação dos intermediários pela introdução do seu licenciamento resultou num aumento das forças inflacionistas e na criação do "mercado negro" oficial em proporções assustadoras. O licenciamento consiste em se restringir o comércio dos artigos escassos às firmas que possuíam tradição do seu ramo ao tempo da introdução de tais dispositivos legais [controle de preços], emitindo-lhes autorizações para continuarem com elas comerciando. Infelizmente, a medida citada não foi posta em execução. Até mesmo nos artigos de importação, em que o controle se tornaria mais fácil, não se procurou limitar o número de intermediários admissíveis entre o importador e o consumidor final. [...] Se o Estado não pode reunir uma centena de funcionários para efetuar o controle de preços, melhor seria, e até mesmo mais honesto, que nada criasse. É coisa sabida que o controle, para ter valor, deve ser eficiente" (Di Pietro, 1946, p. 51-53).

(32) Os controles de preços, bem como outros mecanismos, quando instituídos, se imaginaram como temporários, já que havia a expectativa de que os preços se estabilizassem após o final do conflito mundial, com o reestabelecimento do comércio internacional. Com a desilusão da estabilização no pós-guerra, os mecanismos de controle de preços seguiram sendo ampliados. Como exemplo disso, foi decretada, em agosto de 1946, a Lei n. 9669 com o intuito de regulamentar, fiscalizar e arbitrar todas as 
De maneira geral, o contexto do conflito mundial foi marcado por dois blocos de interpretação do processo inflacionário. De um lado, havia aqueles, como Gudin e Carvalho, que sustentavam a ideia de que a estrutura produtiva brasileira estava sob demanda excessiva, e que isso levava à operação num nível acima do desejável, com impacto sobre os salários, e os excedentes comerciais estariam provocando aumentos inflacionários na base monetária. Ambas as pressões estariam deslocando fatores de produção de setores tradicionais para novos setores, menos eficientes. A solução passaria por uma redução dos estímulos físcais atuantes sobre a economia, e pela retirada de circulação dos excedentes monetários resultantes do superávit comercial. Com a retomada do comércio mundial e das importações, e com o fím do esforço de guerra, a tendência era que ambas as pressões retrocedessem, e o processo inflacionário se arrefeceria. Por outro lado, havia aqueles, como Simonsen e Almeida, que sustentavam ser a inflação fruto das flutuações internacionais de preços e da lentidão na expansão da oferta agrícola, que não acompanhava a evolução da demanda. Nesse caso, a solução passaria por mecanismos regulatórios e estratégias de focalizadas de fomento à produção.

\section{O Pós-Guerra, e a escassez de dólares}

O fim do conflito armado propiciou o retorno à normalidade dos fluxos de importação. Para muitos dos economistas liberais, a entrada massiva de importações teria como resultado a estabilização dos preços, via concorrência externa, e a liberação de fatores de produção para setores tradicionais da estrutura produtiva brasileira. Ao longo de 1947, o influxo de importações de fato se acelerou, e reverteu o saldo do balanço de pagamentos. As exportações se mantiveram num ritmo similar, mas, com o aumento no volume de importações, a balança comercial passou a acumular déficits, e em junho foram declaradas encerradas as reservas de dólares, fazendo eclodir uma crise cambial.

O déficit comercial externo, que se manifestou na América Latina como um todo ${ }^{33}$, foi interpretado como um sinal da escassez de dólares ${ }^{34}$, e houve certa perplexidade diante da persistência da inflação em paralelo com a reversão do saldo do balanço de pagamentos ${ }^{35}$. O reestabelecimento do comércio internacional não implicou na redução dos preços internos, como era esperado; as importações foram retomadas, em grande vulto, mas concentradas, sobretudo, no consumo de bens não produzidos no Brasil, frustrando as expectativas de redução dos preços via acirramento da concorrência:

\footnotetext{
renovações de aluguel, o que na prática significava a extensão dos controles para imóveis residenciais (Mata, 1980). No art. 145 da constituição de 1946, promulgada em setembro de 1946, manifestava-se a necessidade de se conter eventuais abusos de poder econômico, outra novidade no sentido da contenção regulatória da evolução dos preços.

(33) "A diminuição das reservas monetárias brasileiras que vinha se processando nos últimos meses, até julho, não é um fenômeno isolado. Segundo uma estimativa do Economist de Londres, os países da América Latina, em consequência de compras maciças sofreram, em 1947, uma perda média mensal de mais ou menos cem milhões de dólares, em ouro e divisas (Conjuntura Econômica, nov. 1947, p. 21).

(34) Essa expressão se tornou comum no período, e deu, por exemplo, nome ao artigo de Torres, J. G (1948): "Escassez de Dólares, Procura Inatendida, Controles".
}

(35) "Até certo momento, contava-se inclusive com a possibilidade de deflação" (Bielschowsky, 2000, p. 309). 
Os exportadores estrangeiros, manifestando-se terminantemente contra os controles, ansiavam por aproveitar-se das reservas de dólares do Brasil; e o Governo Brasileiro, temendo os efeitos do volume de papel moeda sobre a economia nacional, vacilou na sua política de restrições à importação - pois que o emprego de parte dos dólares em reserva tenderia a diminuir o perigo da inflação e resultaria na entrada de certos bens de consumo que o Brasil, devido à falta de equipamento de produção, não podia fabricar para si. Infelizmente, a febre de importar ultrapassou até mesmo as expectativas governamentais, em parte por causa dos métodos de pressão, usados por alguns vendedores estrangeiros que agiram, não com a ideia de criar um mercado estável, firme e crescente, mas de vender tudo o que pudessem, e tão depressa quanto possível. Importadores ávidos (...) encomendaram, indiscriminadamente, produtos úteis e produtos supérfluos: compraram arame ... e uísque; folha de flandres ... e lata dourada. (...) Em 1947 - só por bebidas o Brasil pagou 17 milhões de dólares (...) (Torres, 1948, p. 57).

A discussão centrou-se na busca por uma solução para a urgente crise cambial. Abandonada a ideia de que o livre comércio seria a solução para o problema da inflação, e diante do desequilíbrio do balanço de pagamentos, o debate se estabeleceu entre as opções de desvalorização do cruzeiro e do controle seletivo de importações. Azevedo (1948b) ressaltava a prioridade do controle da inflação, e resistia à ideia de desvalorização cambial, potencialmente inflacionária. Rômulo de Almeida, ainda em 1946, havia percebido que o déficit externo era um problema no horizonte, e que havia certa tolerância das nações líderes a exceção dos EUA - com relação ao controle de importações ${ }^{36}$ :

Medidas para o [b]alanço de pagamentos - restrições de importação para salvaguardar os balanços de pagamento, em situação de déficits incuráveis pelos créditos acessíveis e outros recursos, e para preservar reservas monetárias escassas e permitir-lhes alcançar um razoável acréscimo, consultando-se sempre, antes ou logo depois, de impostas as restrições a Organização e o fundo. Podem-se assim, selecionar as importações conforme as conveniências para os programas de desenvolvimento do emprego, de reconstrução, de desenvolvimento ou de caráter social (Almeida, 1947, p. 43).

Haberler (1947, 1948), economista austríaco, radicado nos EUA e professor de Harvard próximo a Gudin, entendia o resultado negativo no balanço de pagamentos dos países latinoamericanos como fruto da reafirmação da supremacia econômica e produtiva dos EUA no cenário do pós-guerra ${ }^{37}$. Afirmava ser necessário evitar a desvalorização, já que se trataria de

(36) “foi permitido, dentro de certos limites, o controle de importações, sujeito, porém, à consulta com os países que se julguem prejudicados, para o reajustamento das indústrias desenvolvidas com a guerra; foi permitido, dentro de certos limites, o uso de restrições à importação de artigos de consumo, quando a importação prevista de bens de produção ameaça desequilibrar o balanço de pagamentos" (Almeida, 1947, p. 41).

(37) "Pode haver dúvida de que esteja sofrendo, praticamente, o mundo inteiro, de uma tremenda escassez de dólares? (...) se o comércio entre os Estados Unidos e o resto do mundo se mantivesse em equilíbrio num regime de mercado livre, a relação de trocas teria que se deslocar, francamente, a favor dos Estados Unidos e contra os outros países. Isso acarretaria em alguns desses países, especialmente a Grã-Bretanha, uma queda do padrão de vida social e politicamente (se não também física e economicamente) intolerável. Se se tentasse impor essa espécie de equilíbrio, seria impossível resistir à exigência de salários e ordenados mais elevados, o que conduziria outra vez à inflação, com repetição do desequilíbrio do balanço de pagamentos e da escassez de dólares ou, no caso de opor resistência à inflação pela política monetária, isto conduziria ao desemprego e a uma depressão séria" (Haberler, 1948, p. 7, 24). 
uma manipulação monetária superficial, que não atuaria nas causas do problema, com impactos sobre o padrão de vida da população local ${ }^{38}$. Apesar de sua orientação liberal, Haberler foi mais um a defender a atuação do Estado na restrição às importações ${ }^{39}$. Uma eventual desvalorização encareceria as importações, e dificultaria a renovação do parque industrial, algo que se fazia necessário naquele contexto para os chamados "países novos":

[Há] os países novos que, além de devedores, precisam ainda de capital para o seu desenvolvimento econômico. A guerra apanhou-os em pleno esforço de criação de indústrias nacionais; em certos ramos as necessidades criadas pela paralisação das trocas internacionais fizeram com que a produção industrial crescesse muito, mas terminada a guerra estes países sentiram que, num futuro próximo, terão que lutar contra a concorrência internacional, ficando em condições desfavoráveis se não reequiparem seu parque industrial, eliminando o equipamento obsoleto (Haberler, 1947, p. 94).

Menezes (1947) se somava aos autores que entendiam a desvalorização como um mecanismo inadequado para reequilibrar as contas externas. Argumentou, que tal política, na prática, traria benefícios aos exportadores, em detrimento da classe trabalhadora ${ }^{40}$, que teria que lidar com o aumento de preços-chave para a economia brasileira:

Se um país tem sua moeda depreciada, sua "relação de trocas" com o estrangeiro tornase desfavorável, - porque passa a pagar maior quantidade de mercadorias a mesma quantidade que importava anteriormente. (...) O lucro que decorre dessa diferença de preços (...) é repartido entre o exportador nacional e o estrangeiro - esclarece Eugênio Gudin. Ambos, pois, se irmanam no lucro obtido. (...) Quem pagou o prejuízo? A nação, isto é, a parte ativa e trabalhadora da nação, que viveu em regime de privação forçada, típica do estado inflacionário (Menezes, 1947, p. 29).

Dentre os autores que defendiam outras soluções alternativas, é possível mencionar Souza (1948), que defendia a adoção de câmbio múltiplo, mas, de modo geral, houve certa convergência com relação à necessidade de se evitar a desvalorização cambial. A proposta que

(38) "Nos casos de inflação (...) pouco adiantará o expediente da desvalorização porque o aumento exagerado do meio circulante é sempre um sintoma de causas mais profundas e, nestes casos, o que se deve combater são as causas e não os efeitos" (Haberler, 1947, p. 95).

(39) Dentre as formas de se restringir as importações, Haberler apontou as tarifas alfandegárias como superiores à concessão de quotas de importação, por expandirem o potencial arrecadatório: "Há (...) uma diferença fundamental entre a proteção estabelecida pelo sistema de quotas e a estabelecida pelo sistema de tarifas. Nesta última, o rendimento da tarifa vai para o Tesouro Nacional, fornecendo ao Estado recursos que lhe permitem exercer, mediante créditos, prêmios à produção e assistência técnica e econômica, uma política efetiva de proteção direta à produção nacional. No caso do estabelecimento de quotas e controle de câmbio a diferença de preços provocada por este regime (uma vez que, em ambos os casos, a consequência é uma elevação de preços no mercado interno) fica nas mãos do comerciante não havendo certeza da possibilidade da produção nacional ser beneficiada com o emprego dos lucros obtidos. São os particulares que se enriquecem, muitas vezes até com prejuízo daquela" (Haberler, 1947, p. 57)

(40) Vieira entendia que era necessário algum amparo à produção exportadora, mas argumentava não serem suficientes instrumentos monetários: "Os fatos, apontados pelos que labutam nestes setores da atividade econômica nacional [exportação], indicam antes problemas de estrutura; ligam-se aos processos de produção e não podem resolver-se por meros paliativos de caráter puramente monetário. Não negamos que os produtores de semelhantes artigos devam ser amparados. Julgamos, porém, que a desvalorização do cruzeiro não representará uma forma eficiente de amparo" (Vieira, 1949, p. 72). 
prevaleceu foi a de restringir administrativamente as importações, mesmo entre autores de tradição liberal ${ }^{41}$ :

A (...) providência adotada, foi a instituição do controle do câmbio e o estabelecimento da prioridade cambial, de acordo com o critério de essencialidade determinado pelo governo. Deste modo, a pressão sobre o nível dos preços internos foi evitada e houve alguma certeza de que as reservas em divisas fossem usadas no legítimo interesse do povo. Estas medidas foram coroadas de êxito, pois tornaram a balança comercial favorável em agosto e setembro de 1947, pela redução das importações (Kershaw, 1948, p. 48).

O livre-cambismo perdeu, então, por força de uma crise cambial, substância no Brasil, assim como em outros países acossados pela escassez de dólares. Randall Hinshaw, economista egresso do Federal Reserve Board, graduado na Universidade de Princeton, e que então trabalhava no Plano Marshall em Paris, percebeu a defesa da liberdade comercial como uma retórica conveniente para a nação líder:

[A] posição americana a favor da não discriminação [do comércio] se baseava no conhecimento de que os Estados Unidos, desfrutando forte posição econômica internacional, pouco teriam a ganhar se praticassem a discriminação e muito perderiam se outros a adotassem. Vista desse ângulo, a insistência americana na igualdade de tratamento parecia a alguns observadores estrangeiros ser antes uma forma de idealismo bem calculado em benefício próprio; pequena significação teria para as necessidades dos países alquebrados pela guerra, que enfrentavam uma 'carência de dólares' aguda (e possivelmente crônica) (Hinshaw, 1948, p. 88).

$\mathrm{Na}$ esteira desses movimentos nos arranjos ideológicos com relação ao comércio internacional, a frustração das expectativas a respeito da trajetória da inflação deu visibilidade a leituras e diagnósticos alternativos para o problema. A persistência da aceleração de preços, mesmo após uma mudança abrupta de conjuntura, passou a ser uma evidência de que a falta de importações e a esterilização dos superávits comerciais - que agora já não se manifestavam não seriam suas causas. Emergiram, então, outras explicações para o processo inflacionário, que passaram a ter uma leitura menos mecanicista/universalista do fenômeno, destacando a diversidade de tipos de inflação:

(...) é preciso discriminar diversos tipos de inflação, os quais implicam cada um seus problemas próprios e exigem remédios específicos. Frequentemente, as medidas aplicadas no combate à inflação ficam ineficazes, pois não se toma conta desse fato fundamental da política monetária. Medidas adequadas para uma inflação ligeira fracassam na fase de hiperinflação, e restrições necessárias na hiperinflação arruínam a economia de países atingidos apenas por uma inflação ligeira (Lewinsohn, 1948, p. 31).

Como corolário do surgimento de tipologias para diferentes formas de inflação, as análises a respeito das consequências do processo inflacionário também se diversificaram.

(41) "Vê-se, assim, que eram os próprios líderes do pensamento livre-cambista que legitimavam as medidas intervencionistas, paradoxalmente adotadas naqueles anos áureos de política econômica liberal no Brasil” (Bielschowsky, 2000, p. 312). 
Cada tipo de inflação teria características particulares, e consequências para o ordenamento socioeconômico também particulares. Os desequilíbrios intersetoriais, os impactos sobre preços relativos e o conflito distributivo ${ }^{42}$ resultantes do processo inflacionário entraram na ordem do dia:

Ora, na inflação os distúrbios se processam desigualmente, porque certos setores da economia se adaptam mais rapidamente e outros só muito tarde começam a acusar seus efeitos iniciais. O setor agrícola marcha atrasadamente em relação aos efeitos indicados. Há certo coeficiente de retardamento nesse jogo de forças à busca de novo equilíbrio - e os mais retardados sofrem mais prejuízos. Mas a importância do problema reside na consideração dos "preços relativos" e não, em primeiro lanço, no nível de preços (Menezes, 1947, p. 27).

As políticas anti-inflacionárias passaram, então, a ser interpretadas considerando seus efeitos sobre o desenvolvimento econômico ${ }^{43}$. Ora, se cada tipo de inflação enseja resultados distintos sobre a economia, e demanda remédios específicos, o policy maker teria então que escolher, caso a caso, a política ideal, entre diferentes possibilidades, com desempenho melhor ou pior a depender da acuidade da escolha. Mais ainda, as interpretações sobre o problema inflacionário brasileiro voltaram-se cada vez mais para as condições da estrutura produtiva. Para um número crescente de economistas, a inflação brasileira deveria ser entendida como um fenômeno intrinsecamente associado à dinâmica da produção nos diferentes setores da economia:

Não se deve concluir que estão no plano monetário e bancário as causas das principais perturbações e crises de que padece o nosso sistema econômico. Deslocando-se dessa maneira as causas que produzem os males, fica-se a procurar naquela esfera os remédios. Fala-se muito na quantidade de moeda, na sua estabilidade, nos índices de preços, nos programas deflacionistas ou inflacionistas, em tudo que se prende às questões monetárias e bancárias. Desaparecem de nosso pensamento os problemas profundos, que subjazem a todas aquelas relações: os problemas da produção, derivados das forças produtivas; as condições de trabalho, de salário, de custo de produção, do lucro, etc. No entanto, é nas forças produtivas que estão os problemas fundamentais, que determinam, como consequências, todos os demais. Apenas, dada a interdependência desses fatos sociais, os efeitos refluem sobre as causas, operando como efeitos-causas, e criando esse tecido complexo de reciprocidade. É justamente isso que permite a elaboração de teorias monetaristas - queremos dizer, que permite a idealização de explicações que reputam a superestrutura monetária o fator principal na produção dos fenômenos (Menezes, 1948a, p. 34).

A interpretação de Menezes é um exemplo de como a manifestação monetária dos preços passou a ser analisada em conjunto com a dinâmica produtiva. A correspondência entre

(42) "podemos dizer que a inflação produz malefícios em escala variável, que atinge as diferentes classes ou categorias de indivíduos da sociedade, infligindo-lhes seus efeitos por forma tal que uns saem visivelmente castigados, enquanto que outros parecem beneficiados..." (Azevedo, 1948a, p. 46).

(43) "Foi muito louvável a sua resolução de suspender as emissões de papel-moeda, a fim de combater a inflação. Mas, desde o momento em que a consequente paralisação do crédito à produção começa a causar graves prejuízos à economia nacional, é justo que você procure sanar esse mal" (Loureiro, 1949, p. 71). 
moeda e inflação não é negada, mas entendida em conjunto com a produção. A aceleração de preços não se devia à expansão da quantidade de moeda per se, mas fundamentalmente às relações entre moeda e estrutura produtiva ${ }^{44}$. Para o autor, a análise isolada da quantidade de moeda não teria sentido econômico:

O que está movimentando esse nível de preços, portanto determinando as flutuações do poder de compra? Evidentemente, a quantidade de mercadorias e serviços que se oferecem pela moeda. Esse poder de compra se gera no processo produtivo e se manifesta no processo circulatório, dois processos de ajustamento mútuo. O governo emite os signos monetários - mas é o processo produtivo que dá origem ao poder aquisitivo. Se esse poder aquisitivo permanece o mesmo, uma maior quantidade de moeda tende a distribuí-lo, a rarefazê-lo nas unidades monetárias (Menezes, 1949a, p. 55).

Linhares e Montalegre ${ }^{45}$ estabeleceram leituras similares à de Menezes, e o primeiro destacou a compatibilidade da interpretação da inflação como fenômeno associado ao processo produtivo com a Teoria Quantitativa da Moeda, criticando os efeitos recessivos de políticas monetárias contracionistas:

Hoje no Brasil, poderemos dizer, sem contrariar a teoria quantitativa, que o valor da moeda decresce sem aumento ou mesmo com diminuição do seu volume, desde que estamos presenciando um contínuo decréscimo da produção, que se reflete na diminuição da oferta de mercadorias. Com preços em contínua ascensão, não mais devido ao aumento do meio circulante mas ao decréscimo da produção, não se pode continuar com essa política de não emitir (...) A moeda tem que ser elástica. Se o seu aumento concorre para a elevação dos preços, estes podem, e muitas vezes o temos visto, determinar o aumento do meio circulante ou a sua velocidade de circulação, tornando-se causas em vez de efeitos. O que constitui um crime é essa política desalentadora das atividades produtivas a pretexto ou com intuitos de reprimir atividades especuladoras. A verdade é que a especulação se alimenta dessas dificuldades criadas a título de combatê-la (Linhares, 1949, p. 95).

A perspectiva de Linhares, assim como a de Menezes, tem a inflação como um resultado possível da retração da produção, num contexto em que a base monetária se mantém constante. Nessa leitura, seria possível ter os preços em aceleração, ao mesmo tempo em que se gera desemprego, o que fez reacender a controvérsia sobre a existência ou não de pleno emprego na economia brasileira. Menezes argumentava haver um enorme contingente de desempregados, que agia como mecanismo moderador dos salários. Aumentos nos salários poderiam ocorrer como resultado de uma redução significativa do exército de reserva em ausência de progresso técnico. Mas, o volume de desempregados seria, no Brasil de então, tão

(44) Essa lógica seria válida também no âmbito da economia internacional, e os volumes de ouro: "Houve um projeto para se proceder à repartição internacional do ouro. Este não resiste a cinco minutos de análise séria. A saúde dos padrões monetários depende, antes de tudo, do equilíbrio geral da produção, da probidade orçamentária e seu equilíbrio, da tributação suportável e do equilíbrio da balança internacional de pagamentos" (Menezes, 1948a, p. 37).

(45) Montalegre destacou, em particular, a questão da produtividade como determinante para a dinâmica de preços: "Qual então a solução que se oferece a fim de que se ponha um paradeiro a esta ânsia pelas alturas dos números de valores monetários? Só há uma visível: o aumento da produção por homem, reduzindo seu custo unitário por unidade de salário pago" (Montalegre, 1948, p. 39). 
elevado que não se poderia imaginar inflação de salários como resultado do excesso de estímulo monetário:

Quando o capital se acumula sem que se realizem grandes progressos técnicos, cresce o volume de emprego, diminuindo o lastro dos sem-trabalho, e, consequentemente, possibilitando a subida dos salários reais. Existe sempre, em nossos meios rurais, larga massa de desocupados, que torna a oferta do braço muito depreciada: é o mínimo necessário para a sua miserável subsistência que nessas circunstâncias determina o salário real (Menezes, 1948b, p. 57).

Com as atenções voltadas para a estrutura produtiva, a predominância agrícola na produção brasileira, e a consequente inserção comercial internacional primário-exportadora, surgiu como potencial explicação para a inflação. Torres atentou para a assimetria nas trajetórias de preços do comércio global, identificando um descompasso no preço pago pelas mercadorias importadas e as exportadas, o que pode ser interpretado como uma antecipação da noção de deterioração dos termos de troca ${ }^{46}$. Gudin referira-se ao caráter "reflexo" da economia brasileira, que por seu padrão de especialização reagia reflexivamente aos movimentos do mercado global. A dinâmica dos países centrais, então, condicionava a evolução da economia nacional, incapaz de determinar sua própria trajetória, dado seu padrão de inserção como fornecedora de insumos para outros sistemas econômicos. Na mesma linha, Vieira (1948) afirmava ser o retorno extraído do comércio internacional menor para países exportadores de matéria-prima, e a instabilidade uma fatalidade inerente a esse padrão de especialização:

Por isso é que se afirma possuírem os países latino-americanos, de que é um exemplo o Brasil, economia reflexa, ou seja, de fraca industrialização e grande fornecedora de matérias-primas. (...) têm uma exportação cujo valor específico é fraco e uma importação de valor específico forte; dependentes como são, acabam dando quase de graça aquilo que produzem, pagando cada vez mais caro o que recebem; tendo uma economia de base agrícola quase exclusiva estão sujeitos a irregularidades no ritmo e volume de produção típicos da agricultura, que pela impossibilidade de controle humano das condições atmosféricas, quer por não poderem empregar, em grande escala, o maquinismo e usufruir-lhe as vantagens (Vieira, 1948, p. 68).

A intersecção entre essas análises, que enfocavam de um lado o padrão submetido de inserção da economia brasileira na economia global, e de outro a trajetória cadente dos preços relativos das exportações brasileiras, se tornou protagonista no debate sobre inflação. Preços de importações sempre crescentes, e de exportações sempre cadentes, seriam uma razão potencial para o processo inflacionário em curso. O poder de compra da moeda nacional estaria, nesse movimento, se deteriorando em relação à moeda internacional de referência, e dada a dependência de importações para abastecer o mercado interno, essa perda de poder de compra inevitavelmente se traduziria em inflação. Paralelamente, afirmava-se que as oscilações de preços teriam efeitos desastrosos para economias altamente especializadas como a brasileira,

(46) "Quando o Brasil importa - quase sempre dos Estados Unidos - paga mais; quando exporta, recebe proporcionalmente menos e menos. Assim é que, para receber divisas em quantidades iguais às que tem de despender, o Brasil precisa vender muito mais do que compra" (Torres, 1948, p. 58). 
com surtos de alta e baixa na renda nacional provocados por movimentos externos e com impactos sobre a dinâmica interna de preços. Todas essas percepções foram posteriormente fortalecidas pelas contribuições da Cepal, mas já sinalizavam uma nova interpretação para as causas do processo inflacionário:

Por seu lado, as condições características da economia brasileira de país essencialmente fornecedor de produtos tropicais, na maior parte matérias-primas, e com uma agravante de acentuada tendência para a monocultura do café, davam-lhe a feição de uma unidade comercial exportadora (...). Desta maneira, a "tesoura dos preços", sempre aberta em prejuízo dos países agrícolas, (...) deixava-nos à mercê das cotações impostas pelos grandes países industriais, consumidores de nossos produtos de exportação. A desvalorização da moeda, nessas condições, permitindo retirar das exportações preços mais elevados em moeda nacional, apenas servia em proveito dos exportadores, as mais das vezes intermediários - estrangeiros ou nacionais gananciosos - entre os verdadeiros produtores da nossa riqueza e os seus mercados consumidores (Linhares, 1948, p. 134135).

A análise que Gudin apresentara em "Inflação e Economia de Guerra" (1944), que apontava o superávit comercial do período de guerra como inflacionário, perdeu, então, nesse cenário, sua força. A economia brasileira havia voltado a ter acesso a importações, e as exportações retrocederam, sem que fosse controlada a inflação. As novas leituras dos economistas inverteram a pergunta, e passaram a questionar como fomentar a estrutura produtiva brasileira de forma a responder à demanda crescente, demanda esta que deixou de ser entendida como um caso excepcional do período de conflito:

O movimento dos preços, que então se verificava, tinha suas raízes em modificações na esfera produtiva, nos desequilíbrios fundamentais entre os investimentos em bens de produção e bens de consumo, com as repercussões do fenômeno nas demais áreas de atividade econômica. A escassez dos bens de consumo em face de uma procura crescente, a dificuldade de transportes pela agressão marítima, as exigências do mercado internacional sob as circunstâncias de guerra, a ineficiência do controle governamental sobre os preços base, a especulação dos incorporadores, os capitais mal dirigidos dos organismos paraestatais, - tudo se soma para forçar a alta dos preços e a situação de crise posterior. Deslindar, nessa trama de cousas multiplamente variáveis, uma causa única, que responda por todos aqueles efeitos, é uma puerilidade já desfeita pela crítica dos de senso comum, que não é comum, entretanto, a alguns especialistas excessivamente fechados na sua especialidade (Menezes, 1949b, p. 70).

Diante dessa nova perspectiva analítica que se construía, Gudin arrefeceu sua percepção de que a inflação seria causada pela evolução monetária. Numa leitura à Keynes, ressaltou características institucionais da economia e do comportamento dos agentes econômicos que impediriam o repasse da redução de custos - oriunda do progresso tecnológico - para preço $0^{47}$. Haveria, assim, uma assimetria na formação de preços, como resultado dessa

(47) “Contra essa orientação, de um nível de preços baixando na razão inversa da produtividade, defrontam-se motivos de ordem psicológica e de ordem social. Um é que as classes operárias e especialmente os Sindicatos preferem que a vantagem da melhoria do rendimento real se traduza sob a forma mais tangível de uma aumento de salários monetários - Não é só - Os 
rigidez, que impediria as reduções. Em seguida, reproduziu trechos de relatórios do Federal Reserve $^{48}$ demonstrando a complexidade do fenômeno inflacionário, a impossibilidade de contê-lo exclusivamente a partir de mecanismos monetários e a necessidade de se considerar objetivos mais amplos do que o controle inflacionário ao se desenhar uma política monetária:

A correlação entre estabilidade de preços e estabilidade econômica não é [...] bastante estreita para que se restrinja o objetivo da política monetária à estabilização de preços [...] A direção do sistema monetário do país não sendo uma ciência exata, uma vez que abrange previsões e lida com muitas incertezas, é essencial que ao determinar-se o seu objetivo, deixe-se a indispensável margem para julgamento e discrição.[...] O sistema de Reserva Federal pode, dentro de certos limites, regular a quantidade de moeda, mas há outros fatores que afetam os preços e a atividade dos negócios tão fortemente quanto a quantidade da moeda. Muitos desses fatores são amonetários. [...] Os fatores monetários são um apenas dos grupos de forças que influem sobre a atividade econômica [...] o Conselho entende que a estabilidade econômica e não a estabilidade de preços deve constituir o objetivo geral (Gudin, citando Boletim do Federal Reserve, 1949b, p. 12).

Reconhecida a necessidade de intervir no sistema econômico a partir de uma perspectiva mais ampla, visando objetivos múltiplos, e considerando as idiossincrasias de cada sistema econômico, a questão passou a ser como canalizar os escassos recursos de uma economia periférica para a solução de dificuldades estruturais e para a produção dos bens necessários para a continuidade do processo de crescimento, sem gerar instabilidade econômica e monetária. A situação de atraso relativo de um certo número de países que nas trocas internacionais absorviam parcelas cadentes de valor relativo precisava ser levado em conta ao se desenhar políticas econômicas. O laissez-faire e o mecanicismo monetário ganharam, naquele contexto, conotação de instrumento garantidor do status quo, parte de discursos externos interessados ${ }^{49}$, e se difundiu, ainda que de maneira desorganizada, uma consciência sobre a necessidade de intervir-se planejadamente na realidade concreta para superar tal situação de atraso. Foi essa a argumentação que alimentou o desenho de uma política de restrição às importações, que visava, a rigor, contornar a desvalorização, potencialmente inflacionária, do cruzeiro.

empreendedores e homens de negócios nunca são simpáticos a uma política de redução de preços; o seu bem-estar econômico parece estar condicionado ao sopro de uma aragem, por leve que seja, de alta de preços; eles são, intrinsecamente, favoráveis à tendência inflacionista, ainda que moderada. É claro que eles são vítimas de uma ilusão; seus sobrelucros são, muitas vezes, imaginários e obtidos uns à custa dos outros. Mas real ou ilusório, o estímulo à atividade econômica e ao pleno emprego é efetivo" (Gudin, 1949b, p. 10).

(48) “[D]estacam-se os [pareceres] publicados nos Boletins da Reserva Federal de setembro de 1937 e de abril de 1939 , donde destacamos os seguintes e expressivos trechos [...]" (Gudin, 1949b, p. 11).

(49) "Os teóricos de nações mais avançadas elaboram teorias artificiosas que servem aos interesses dos seus respectivos países (e a história das doutrinas econômicas está aí para comprovar. Os países atrasados são frequentemente iludidos - ou porque seus delegados sejam ludibriados pelas teorizações, ou porque se deixam arrastar por motivos menos lisonjeiros. O certo é que cedo acordam dessangrados nas suas mais profundas fontes de vida coletiva. Porque, com a desigualdade das taxas de trocas, estão entregando, sob a capa das transações monetárias, produtos de 15 dias de trabalho agrícola por produtos de 1 dia de trabalho industrial. É um sistema esgotador, que beneficia as nações fortes e aparelhadas" (Menezes, 1949c, p. 84-85). 


\section{Conclusão}

Esse artigo abordou a evolução do pensamento brasileiro sobre a inflação no período entre 1939-1947. Primeiro, foram apresentados os principais argumentos para explicar a inflação em ambos os lados da controvérsia entre desenvolvimentistas e liberais, no período da Segunda Guerra Mundial.

Simonsen, dentre os desenvolvimentistas, propunha a aceleração do processo de industrialização brasileiro, com os instrumentos disponíveis, para promover a ampliação da oferta de produção interna. A industrialização progressiva conduziria ao desenvolvimento, e a redução da dependência da oferta externa conduziria a preços variáveis dos produtos industriais. Além disso, criticou a maneira mecanicista como muitos apresentavam a relação entre moeda e preços, e se mostrou favorável aos mecanismos de crédito seletivo. Não discute, no entanto, estratégias para a contenção dos preços a curto e médio prazo, ressaltando apenas o caráter particular do contexto vivido durante a guerra, e a falta de investimentos para a agricultura, que crescia num ritmo inferior ao da indústria.

Gudin, por seu turno, acompanhado por Carvalho, destacou-se entre os liberais e dedicou-se muito particularmente à questão da inflação. A causa da inflação, para ambos, estava associada ao excesso de demanda e a um montante demasiadamente elevado de recursos monetários atuando sobre a estrutura produtiva brasileira. A particularidade do contexto de conflito mundial impedia o Brasil de importar para atender à demanda interna, e gerava a acumulação de superávits comerciais, que aplicados internamente exageravam a oferta monetária, causando inflação. O crescimento da indústria teria ocorrido como resultado desse sobre-estímulo, inflando a demanda por emprego no setor e, consequentemente, o custo do trabalho em todo o sistema econômico. Os déficits fiscais seriam outro fator a pressionar a demanda agregada, elevando ainda mais os salários, e promovendo uma transferência intersetorial de recursos.

Bulhões e Kingston estiveram em linha com Gudin na interpretação de excesso de demanda e de estímulos monetários, mas preocuparam-se particularmente com as margens de lucro excessivas praticadas por produtores nacionais atuando num mercado protegido. Almeida, em marcante contraste ao pensamento de Gudin, afirmava haver no Brasil excedentes de mão de obra dedicados a atividades de subsistência, passíveis de serem incorporados aos setores industriais, de produtividade mais elevada. Contraria, portanto, a ideia de que a inflação seria resultado de uma escassez de mão de obra disponível.

Com o fim do conflito armado e a retomada dos fluxos de comércio internacional, as percepções do fenômeno inflacionário alteraram-se. A economia brasileira passou a performar déficits comerciais e esgotou suas reservas internacionais sem que a inflação retrocedesse, fragilizando o argumento de Gudin. O debate centrou-se, então, na busca por soluções para a crise do balanço de pagamentos, e desenvolvimentistas e liberais concordaram em adotar restrições administrativas às importações, como forma de reduzir o déficit externo. Essa estratégia foi consensualmente percebida como aquela capaz de, ao mesmo tempo, reverter o 
déficit comercial e evitar uma aceleração do processo inflacionário, o que seria potencialmente o resultado de uma desvalorização cambial.

Como fruto dos movimentos na conjuntura, houve uma diversificação das análises do processo inflacionário. Os argumentos passaram a enfatizar o caráter de reflexo e de inserção submetida da economia brasileira, assim como a assimetria na trajetória dos preços do comércio internacional. A inflação deixa de ser entendida como um monólito, e discutem-se os tipos de inflação e a consequente diversidade de causas para o processo inflacionário. Além disso, todo o debate é tomado por um pragmatismo que se afirma pela necessidade de ter objetivos múltiplos ao se desenhar uma política de contenção da evolução dos preços.

Por fim, Gudin, o mais célebre dos representes dos liberais, reconheceu ser o fenômeno da inflação demasiadamente complexo para que seja causado ou contido por instrumentos exclusivamente monetários. Volta-se, assim, ele próprio para as características específicas da economia brasileira como explicação para o recorrente problema da inflação.

\section{Referências bibliográficas}

ALMEIDA, R. O Brasil e a Conferência de Comércio. O Observador Econômico e Financeiro, n. 132, jan. 1947.

ARANHA, J. M. Inflação. Digesto Econômico, ano 1, n. 7, jun. 1945.

ARRARTE, J. C. P. A crise mundial de dólares e o Plano Marshall. Digesto Econômico, ano IV, n. 37, dez. 1947.

AZEVEDO, A. M. A inflação e o custo de vida. Digesto Econômico, ano 4, n. 46, set. 1948 a.

AZEVEDO, A. M. O crédito a moeda o capital. Digesto Econômico, ano 5, n. 49, dez. 1948 b.

BARREIROS, D. P. Atuação da Delegação Brasileira na formulação do Acordo Internacional de Bretton Woods (1942-1944). História, São Paulo, v. 28, 2009.

BASTOS, P. P. Z. Desenvolvimentismo incoerente? Comentários sobre o Projeto do Segundo Governo Vargas e as ideias econômicas de Horácio Lafer (1948-1952). EconomiA, Selecta, Brasília, v. 6, n. 3, p. 191-222, dez. 2005.

BIELSCHOWSKY, R. Pensamento econômico brasileiro: o ciclo ideológico do desenvolvimentismo (1930-1964). Rio de Janeiro: Contraponto, 1988, 2000.

BIELSCHOWSKY, R. Eugênio Gudin. Estudos Avançados, v. 15, n. 41, 2001.

BULHÕES, O. G.; KINGSTON, J. Política monetária para 1947. Revista Brasileira de Economia, Rio de Janeiro, v. 1, n. 1, 1947.

CARVALHO, F. M. A inflação brasileira. O Observador Econômico e Financeiro, Rio de Janeiro, n. 133, fev. 1947. 
CASTRO, N. J. O economista: a história da profissão no Brasil. Rio de Janeiro: Cofecon; Corecon/RJ; Corecon/SP, 2001.

CONFEDERAÇÃO NACIONAL DA INDÚSTRIA. Sugestões para a Conferência de Araxá. Estudos Econômicos, ano 1, n. 3-4, set./dez. 1950.

CONFERENNCIA NACIONAL DAS CLASSES PRODUTORAS. Carta Econômica de Teresópolis, Teresópolis, 1945.

CONGRESSO BRASILEIRO DE ECONOMIA, Rio de Janeiro, 1944. Anais...

CONJUNTURA ECONÔMICA, Rio de Janeiro, ano 1, n. 1, 1947.

CONJUNTURA ECONÔMICA. Aluguéis e preços, estudos especiais. Conjuntura Econômica, Rio de Janeiro, ano IV, n. 4, abr. 1950.

CURI, L. F. B.; CUNHA, A. M. Redimensionando a contribuição de Roberto Simonsen à controvérsia do planejamento (1944-194): pioneirismo e sintonia. In: ENCONTRO NACIONAL DE ECONOMIA, 39, Foz do Iguaçu, 2011. Anais...

CYTRYNOWICZ, R. Guerra sem guerra: a mobilização e o cotidiano em São Paulo durante a Segunda Guerra Mundial. São Paulo: Ed. USP, 2000.

DI PIETRO, J. O controle de preços e seu fracasso no Brasil. Digesto Econômico, ano 3, n. 25, dez. 1946.

DINIZ, O. R. Três depoimentos sobre a Conferência de Teresópolis. Digesto Econômico, ano 1, n. 9, ago. 1945 .

EDITORIAL Digesto Econômico. Estabilização e baixa de preços. Digesto Econômico, ano 1, n. 9, ago. 1945.

FONSECA, P. C. D. As origens e as vertentes formadoras do pensamento Cepalino. Revista Brasileira de Economia, Rio de Janeiro, v. 54, n. 3, jul./set. 2000.

GOMES, A. Economia de Guerra no Brasil. Observador Econômico e Financeiro, ano XIII, n. 154 , nov. 1948.

GONÇALVES, L. E. F. de C. As relações Brasil-Cepal (1947-1964). Dissertação (Mestrado em Diplomacia)-Instituto Rio Branco, Ministério das Relações Exteriores, Brasília, 2011.

GUDIN, E. Inflação e Economia de Guerra. Rio de Janeiro; São Paulo: Civilização Brasileira, 1944.

GUDIN, E. Ensaios sobre problemas econômicos da atualidade. Rio de Janeiro; São Paulo: Civilização Brasileira, 1945. 
GUDIN, E. Análise da situação econômica e monetária do Brasil. Depoimento prestado perante a Comissão de Inquérito Econômico e Social da Assembleia Constituinte. Jornal do Comércio, 1946.

GUDIN, E. [1947]. Princípios de economia monetária. 9. ed. Rio de Janeiro: Agir, 1974.

GUDIN, E. O valor do Cruzeiro. Digesto Econômico, ano 3, n. 24, 1949.

HABERLER, G. von. Protecionismo alfandegário. Digesto Econômico, ano 3, n. 35, out. 1947.

HABERLER, G. von. Escassez de dólares? Revista Brasileira de Economia, Rio de Janeiro, v. 2, n. 1, 1948.

HABERLER, G. von. Balança de pagamentos em regime de papel-moeda, Digesto Econômico, ano 3, n. 36, nov.

HEREMBERG, P. G. Price control in Germany. Review of Foreign Developments, Board of Governors of the Federal Reserve System, Division of Research and Statistics, International Sections, Jan. 1947.

HINSHAW, R. A política de discriminação no comércio internacional. Revista Brasileira de Economia, Rio de Janeiro, Fundação Getúlio Vargas, ano 2, n. 3, set. 1948.

KERSHAW, J. A. Reflexões sobre controle cambial e desvalorização, Digesto Econômico, ano 4, n. 41, abr. 1948.

LEFF, N. H. Política econômica e desenvolvimento no Brasil: 1947-1964. São Paulo: Editora Perspectiva, 1968.

LEWINSOHN, R. Aproxima-se do fim da inflação na Europa? Digesto Econômico, ano 4, n. 47 , out. 1948 .

LEWINSOHN, R. De quanta moeda precisamos? Digesto Econômico, ano 5, n. 50, jan. 1949.

LINHARES, J. Do Mil-Réis ao Cruzeiro. Digesto Econômico, ano 4, n. 46, set. 1948.

LINHARES, J. O entesouramento da moeda. Digesto Econômico, ano 5, n. 52, mar. 1949.

LOUREIRO, O. O. R. A reforma do sistema bancário brasileiro. Digesto Econômico, ano 5, n. 53, abr. 1949.

MANTEGA, G. A economia política brasileira. São Paulo; Petrópolis: Polis/Vozes, 1984.

MATA, M. Controles de preços na economia brasileira: aspectos institucionais e resultados. Pesquisa e Planejamento Econômico, Rio de Janeiro, n. 10, p. 911-954, dez. 1980. 
MENEZES, D. O dinheiro, os preços internos e os internacionais e as crises. Digesto Econômico, ano 3, n. 35, out. 1947.

MENEZES, D. O Banco Central, as ilusões metalistas e a produção. Digesto Econômico, ano 4, n. 41, abr. 1948a.

MENEZES, D. Problemas da produção agrícola. Digesto Econômico, ano 4, n. 42, maio 1948b.

MENEZES, D. Dificuldades do controle monetário. Digesto Econômico, ano 4 n. 48, nov. 1948 c.

MENEZES, D. Dificuldades do controle monetário II. Digesto Econômico, ano 5 n. 49, dez. 1948d.

MENEZES, D. Relações entre o capital das empresas e a instabilidade monetária. Digesto Econômico, ano 5, n. 56, jul. 1949a.

MENEZES, D. Relações entre a instabilidade monetária e o capital das empresas. Digesto Econômico, ano 5, n. 58, set. 1949b.

MONTALEGRE, O. Um fim de ano inflacionário, Observador Econômico e Financeiro, ano XIII, n. 155, dez. 1948.

NORMANO, J. F. Apresentação. Digesto Econômico, ano 1, n. 1, dez. 1944.

ONODY, O. A inflação brasileira. Rio de Janeiro: [s. ed.], 1960.

RIBEIRO, C. L. A inflação e o mecanismo de preços. Digesto Econômico, ano 4, n. 46, set. 1948.

ROLLEMBERG, L. D. Licença prévia e intercâmbio mercantil. O Observador Econômico e Financeiro, ano XVII, n. 198, jul. 1952.

SALLES JUNIOR, A. C. A moeda falsa. Digesto Econômico, ano VIII, n. 87, fev. 1952.

SIMONSEN, R. As crises no Brasil. São Paulo: Editora Limitada, 1930.

SIMONSEN, R. As finanças e a indústria. São Paulo: Editora Limitada, 1931.

SIMONSEN, R. Ordem econômica, padrão de vida e algumas realidades brasileiras. Discurso na Assembleia Nacional Constituinte em 30 de Janeiro de 1934. São Paulo: Editora Limitada, 1934.

SIMONSEN, R. O planejamento da economia brasileira: réplica ao sr. Eugênio Gudin. São Paulo: Comissão de Planejamento Econômico, 1945. 
Patrick Fontaine

SIMONSEN, R. O Plano Marshall: e um novo critério nas relações internacionais. Conferência pronunciada no Clube Militar, Rio de Janeiro, 28 de abril de 1948.

SOUZA, R. P. Paridade cambial do Cruzeiro na presente conjuntura econômica. Digesto Econômico, ano 5, n. 49, dez. 1948.

TEIXEIRA, A., MARINGONI, G., GENTIL, D. L. Roberto Simonsen - Eugênio Gudin. Desenvolvimento: o debate pioneiro de 1944-1945. Brasília: Ipea, 2010.

TORRES, J. G. Escassez de dólares, procura inatendida, controles. Observador Econômico e Financeiro, ano XIII, n. 155, dez. 1948.

VIEIRA, D. T. Meio para remediar a balança de pagamentos desfavorável no Brasil. Digesto Econômico, ano 4, n. 48, nov. 1948.

VIEIRA, D. T. Prováveis efeitos de uma possível desvalorização do Cruzeiro. Digesto Econômico, ano 6, n. 61, dez. 1949. 